\title{
Selling to reluctant drinkers: the British wine market, 1860-1914
}

\author{
By JAMES SIMPSON
}

I n the early 1860 s Gladstone attempted to revolutionize British wine consumption by making substantial cuts to duties and creating new outlets for retail sale. Although imports almost tripled between the late 1850 s and the mid-1870s, this proved not to be a permanent change in drinking habits, as wine consumption then declined for the rest of the century. On the eve of the First World War wine imports were higher than they had been a century earlier, but per caput annual consumption at a bottle and a half remained as it had been in 1815, and was half the level of the early 1870 s. Therefore if a combination of falling production costs and falling transport costs encouraged a major increase in the consumption of a wide variety of foods and beverages in nineteenth-century Britain, this happened only briefly with wine. Why this was the case is an important question, because Britain's growing, and comparatively wealthy, urban population might have provided an important market for producers in southern Europe. For example, if the British had consumed just one-tenth of the French figure in the $1890 \mathrm{~s}$, this would have created a demand for wine equivalent to 18 per cent of Spain's total output, or 14 per cent of Italy's, or 105 per cent of Portugal's. ${ }^{2}$ As it was, the city of Paris consumed about seven times as much wine as the whole of the United Kingdom. ${ }^{3}$ This failure to maintain export markets for products such as wine was a major cause of the low productivity found in agriculture in southern Europe, and contributed indirectly to the low living standards of the region.

The eighteenth and early nineteenth centuries saw considerable innovation in grape and wine production in various parts of Europe, permitting a number of distinctive wines, such as madeira, port, sherry, claret, and champagne to be marketed. Merchants in the centres of production, very often British or of British descent, played a key role in this process, although 
high import duties caused wine to remain a luxury in the home market. The legislative changes of the early $1860 \mathrm{~s}$, together with the more general changes taking place in retailing at this time, such as the wider use of brands, heavy advertising, high sales volumes, and low unit prices presented new possibilities for selling wine. This article argues that the failure to create a mass market for wine was caused by the interaction of two factors: volatility of supply and the difficulties in establishing impersonal exchange mechanisms in place of those based on the personal reputation of economic agents such as wine merchants. Because Britain was a single market supplied mainly by four different wine-producing regions in Europe, it is an appropriate source to show why some commodity chains were more flexible than others. Contemporaries frequently maintained that consumers switched between different types of wines because of changes in taste and fashion, but this article will argue that the changes can be explained, at least in part, by the degree of success that producers and merchants had in overcoming marketing problems. Consumers often received insufficient information to judge the quality of a wine before buying it, and the high price of some wines encouraged cheap imitations, some of which were so bad as to be prejudicial to the health of the drinker.

The article is divided into six sections. The first looks at changes in wine consumption over the nineteenth century, and traces the fortunes of different types of wines. The next section considers the nature of supply volatility and the response by merchants. Because geography placed strict limits to the supply of a particular wine, sudden increases in demand or prolonged shortages caused by vine disease encouraged merchants to purchase wines from other regions. Unless consumers could easily identify product quality prior to purchase, there was a risk that this strategy would damage the market once normal supplies resumed. Section III considers the response of producers of fortified wines (port and sherry) and section IV extends this investigation to French wines (claret and champagne). It is argued that some commodity chains were more successful than others in providing consumers with accurate information on wine quality. Section $\mathrm{V}$ considers the problems associated with the retailing of wines in the United Kingdom and investigates why, unlike some other imported foods and beverages in this period, the commodity chain remained 'production', rather than 'market', led. The final section provides some conclusions.

\section{I}

In early nineteenth-century Britain, wine was considered a luxury product and price was less important in determining demand than other factors, such as changes in fashion and taste. Therefore, despite a rapidly growing population, rising real incomes, and a reduction in import duties of about 34 per cent, aggregate consumption increased by only 16 per cent between $1799 / 1824$ and $1825 / 51$, and annual per caput consumption fell from almost three bottles at the end of the eighteenth century to half that figure 
in the early $1850 \mathrm{~s} .{ }^{4}$ The reduction to $5 \mathrm{~s}$. $9 \mathrm{~d}$. per gallon in 1840 still left duties equivalent to the import price of 'good' sherry, twice that of 'tavern' sherry, and five times that of ordinary table wines. ${ }^{5}$ In the debate on duty reform in the $1850 \mathrm{~s}$, George Porter, the author of The progress of nations, argued that only a major reduction in duties would increase consumption sufficiently to maintain the Exchequer's revenue, 'not so much by inducing persons who are at present consumers of wine to take more of it, as by enlarging the circle into which it would be introduced'. ${ }^{6}$

When Gladstone brought in new legislation in the early 1860s as part of the Cobden-Chevalier Treaty, his aim was to change radically the nature of wine drinking in Britain. By 1862, duties on wines with an alcoholic strength of under $26^{\circ}$ proof (equivalent to $14.8^{\circ}$ Gay-Lussac) had been cut from $5 \mathrm{~s}$. $9 \mathrm{~d}$. a gallon to $1 \mathrm{~s}$, , with stronger ones paying $2 \mathrm{~s} .6 \mathrm{~d} .{ }^{7}$ For fortified wines, such as sherry or port, this was a reduction of 57 per cent; for unfortified wines, the cheapest of which could now retail for under 1s. a bottle, the reduction was 83 per cent. The new legislation also introduced major changes in the retailing of wines. This was especially true of the 'Single Bottle Act' of 1861, which allowed retailers, on the payment of a relatively small licence fee, to sell wine for consumption 'off' their premises. ${ }^{8}$ These changes led to a rapid growth in consumption, with total wine imports increasing from 32.5 million litres in $1856 / 60$ to 78 million in $1871 / 5$ (table 1). Some countries benefited more than others. Imports of French wines, which were rarely fortified and therefore paid the lower duty, grew six-fold, and market share jumped from 8 per cent in the early 1850 s to 40 per cent by the early $1880 \mathrm{~s}^{9}{ }^{9}$ By contrast, fortifying with alcohol was an integral part of the production of sherry and port, and other wines from the Iberian peninsula were also strengthened so that they would keep. ${ }^{10}$ Wine imports from Portugal grew by only two-thirds between $1856 / 60$ and $1871 / 5$, and market share fell from 30 to 20 per cent. By contrast, Spanish imports increased one and a half times, with market share remaining roughly constant at 40 per cent.

\footnotetext{
${ }^{4}$ Calculated from Tennent, Wine, pp. 28, 36.

${ }^{5}$ Dover, in $S$. C. on Impon Duties (P.P. 1852, XVII), p. 653. The duty was equivalent to approximately $35 \%, 46 \%$, and $56 \%$ of the retail price.

${ }^{6}$ Porter, in ibid., pp. 498, 511.

${ }^{7}$ Rates changed in both 1860 and 1861 . Those introduced in 1862 lasted until 1886, when the lower rates were extended to wines of up to $30^{\circ}$ proof. In 1899 the duty was increased to $1 \mathrm{~s}$. $3 \mathrm{~d}$. for wines of less than $30^{\circ}$, and $3 \mathrm{~s}$. for those above that level. For sparkling wines an additional dury was imposed in 1888 of $2 \mathrm{~s}$. $6 \mathrm{~d}$. per imperial gallon, or $1 \mathrm{~s}$. $3 \mathrm{~d}$. if the value of the wine did not exceed $15 \mathrm{~s}$. This was reduced to $2 \mathrm{~s}$. irrespective of value in 1893 and raised to $2 \mathrm{~s}$. $6 \mathrm{~d}$. from 1899 . Finally, ordinary bottled wines paid an additional $1 \mathrm{~s}$. per gallon after 1899 .

${ }^{8}$ The licence fee was between $£ 210$ s. and $£ 10$, depending on the value of the premises. By 1880 , 3,895 licences had been granted to sell wine. Wine dealers, who could not sell wine in quantities of less than 2 gallons ( 12 bottles), paid $£^{5} 5$ s.: Wilson, Alcohol and the nation, pp. 322-3 and tab 25 . See also Briggs, Wine for sale, p. 37.

For example in $1875,95 \%$ of Spanish wines and $98 \%$ of Portuguese paid 2 s. $6 \mathrm{~d}$. a gallon, and $96 \%$ of French wines paid the lower rate of 1s.: S. C. on Wine Duties (P.P. 1878-9, XIV), pp. 315-17.

${ }^{10}$ Ibid., pp. 118-19.
} 
Table 1. Wines retained for home consumption in the United Kingdom

\begin{tabular}{|c|c|c|c|c|c|}
\hline \multirow[b]{2}{*}{ Date } & \multirow[b]{2}{*}{ Total (m. litres) } & \multicolumn{4}{|c|}{$\%$ of wines retained } \\
\hline & & France & Portugal & Spain & Others \\
\hline $1816-1820$ & 21.85 & 3.8 & 55.2 & 19.2 & 21.8 \\
\hline $1821-1825$ & 24.71 & 4.5 & 51.2 & 22.3 & 22.0 \\
\hline $1826-1830$ & 29.72 & 5.4 & 45.6 & 29.6 & 19.4 \\
\hline $1831-1835$ & 28.44 & 4.0 & 43.1 & 34.9 & 18.0 \\
\hline $1836-1840$ & 30.67 & 5.7 & 41.3 & 36.3 & 16.7 \\
\hline $1841-1845$ & 27.86 & 6.4 & 38.4 & 39.2 & 16.0 \\
\hline $1846-1850$ & 28.74 & 5.8 & 40.9 & 39.0 & 14.3 \\
\hline $1851-1855$ & 30.58 & 7.7 & 37.7 & 39.8 & 14.8 \\
\hline $1856-1860$ & 32.47 & 10.2 & 29.6 & 39.8 & 20.4 \\
\hline $1861-1865$ & 49.62 & 20.1 & 24.6 & 41.7 & 13.6 \\
\hline $1866-1870$ & 65.66 & 27.2 & 20.0 & 41.7 & 11.0 \\
\hline $1871-1875$ & 77.97 & 29.2 & 20.4 & 39.9 & 10.5 \\
\hline $1876-1880$ & 75.78 & 37.5 & 19.4 & 33.4 & 9.6 \\
\hline $1881-1885$ & 65.81 & 40.3 & 19.5 & 29.7 & 10.6 \\
\hline $1886-1890$ & 63.28 & 39.3 & 22.7 & 25.8 & 12.2 \\
\hline $1891-1895$ & 65.56 & 38.7 & 23.8 & 23.1 & 14.4 \\
\hline $1896-1900$ & 73.52 & 37.1 & 22.5 & 23.8 & 16.6 \\
\hline $1901-1905$ & 62.28 & 32.7 & 23.3 & 24.6 & 19.4 \\
\hline $1906-1910$ & 54.71 & 30.9 & 25.6 & 23.6 & 19.9 \\
\hline $1911-1916$ & 49.85 & 24.7 & 29.7 & 25.7 & 19.9 \\
\hline
\end{tabular}

Source: Wilson, Alcohol and the nation, tab. 12

The level of wine consumption was not maintained, however, but fell by 30 per cent between $1871 / 5$ and $1909 / 13$ to just over half a million hectolitres on the eve of the Great War, a figure equivalent to little more than 1 per cent of French output. Per caput consumption, which had reached about three bottles in 1873 and 1876 , had halved by $1909 / 13 .^{11}$ The decline in per caput consumption from the 1870 s cannot be explained by a switch to other alcoholic beverages, as the movements in demand both for spirits and for beer were similar to that for wine (figure 1). There are a number of possible explanations for the fall in alcohol consumption in this period, including the growing supply of alternative consumer goods that encouraged a diversification in household expenditure, and the influence of the Temperance movement. ${ }^{12}$ However, these arguments cannot explain why consumers did not switch from spirits or beer to wine. More important here, neither can they explain the changes in the types of wine being drunk over the period. Sherry (figure 2), claret (figure 3), and champagne (figure 4) all saw rapid increases in consumption at one moment or other, but then experienced a decline. For sherry, this decline can be dated from the early 1870 s, for quality claret from the early 1880 s, for ordinary claret

\footnotetext{
${ }^{11}$ From 0.56 to 0.26 gallons: Wilson, Alcohol and the nation, pp. 332-3.

12 Gourvish and Wilson, British brewing industry, ch. 2. Before 1900 the slight decline in per caput consumption of beer and spirits was compensated by the growth in population and exports, leading one historian to claim that, in the nineteenth century, 'temperance had promised much and delivered little': Weir, 'Obsessed with moderation', p. 96.
} 


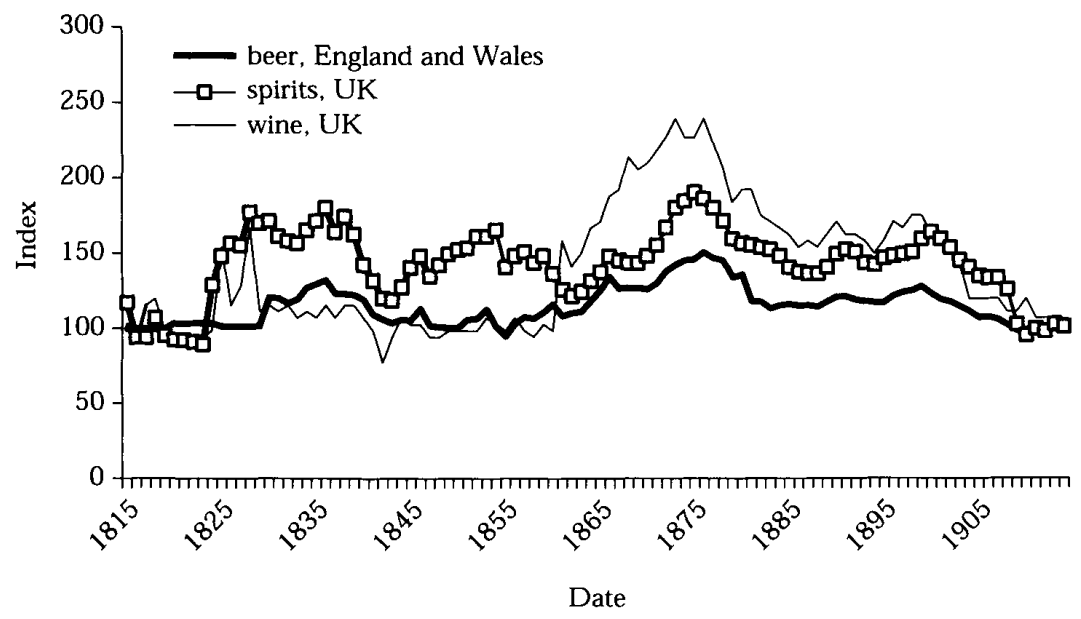

Figure 1. Alcohol consumption per head, 1815-1914

$1815 / 24=100$

Source: Wilson, Alcohol and the nation, pp. 331-3

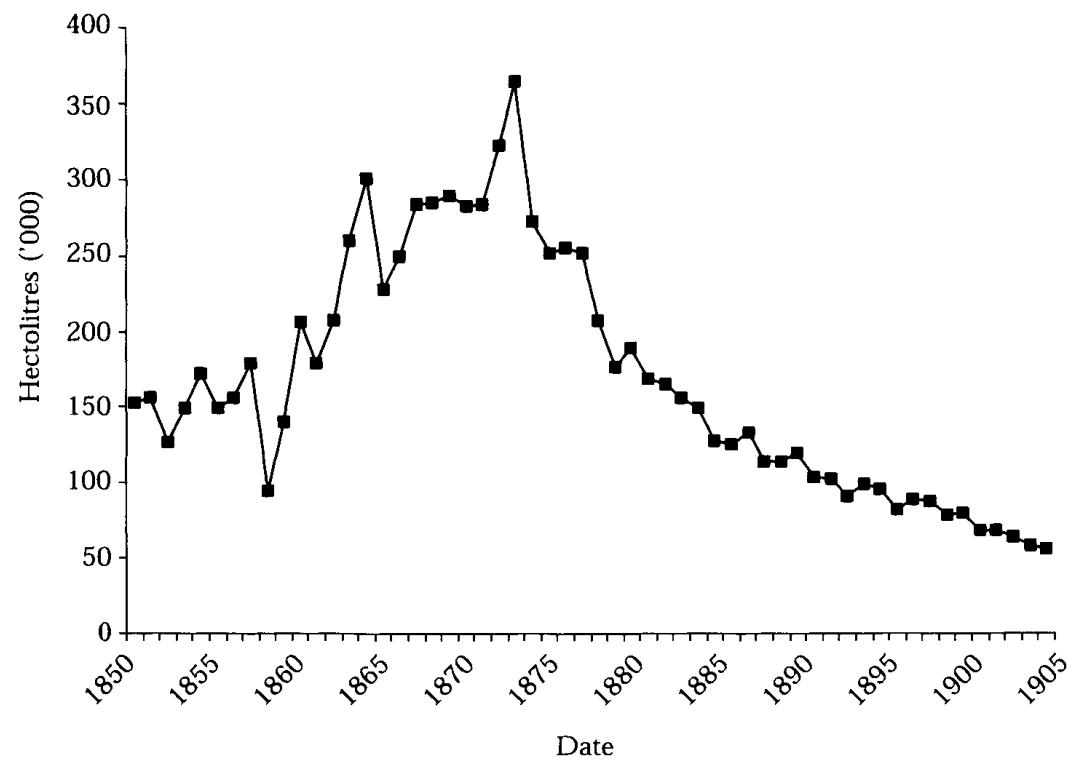

Figure 2. Imports of sherry and Spanish wine, 1850-1905

Source: Wilson, Alcohol and the nation, pp. 362-3; Ridley's, various years 


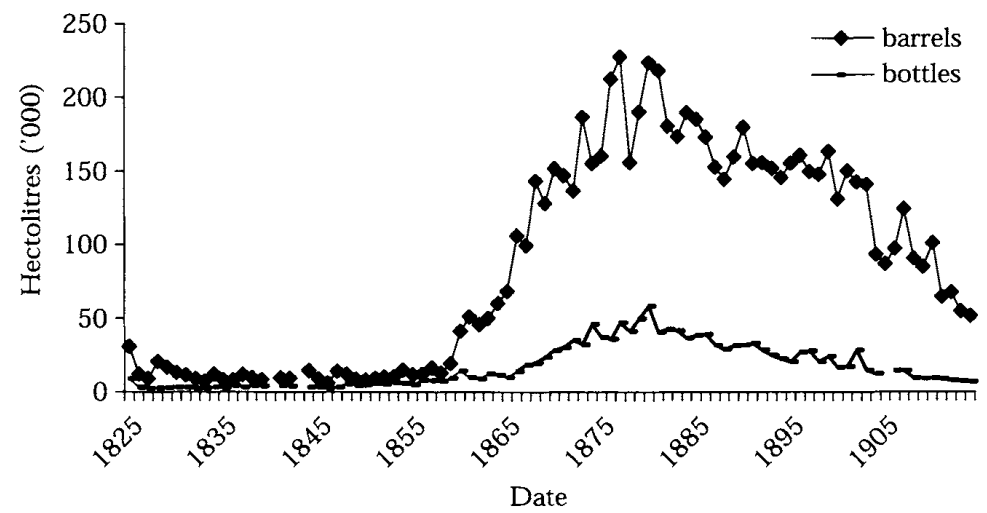

Figure 3. Wine exports from Bordeaux to Britain, 1825-1911

Source: Tableau Général du Commerce

from the late 1880s, and for champagne from about 1900. Although port wine avoided the sharp downturn in imports prior to the First World War, it also experienced fluctuations in demand over the century (figure 5). Before looking more closely at these different wines, it is necessary to consider briefly the supply side, and especially the importance of vine diseases in the nineteenth century.

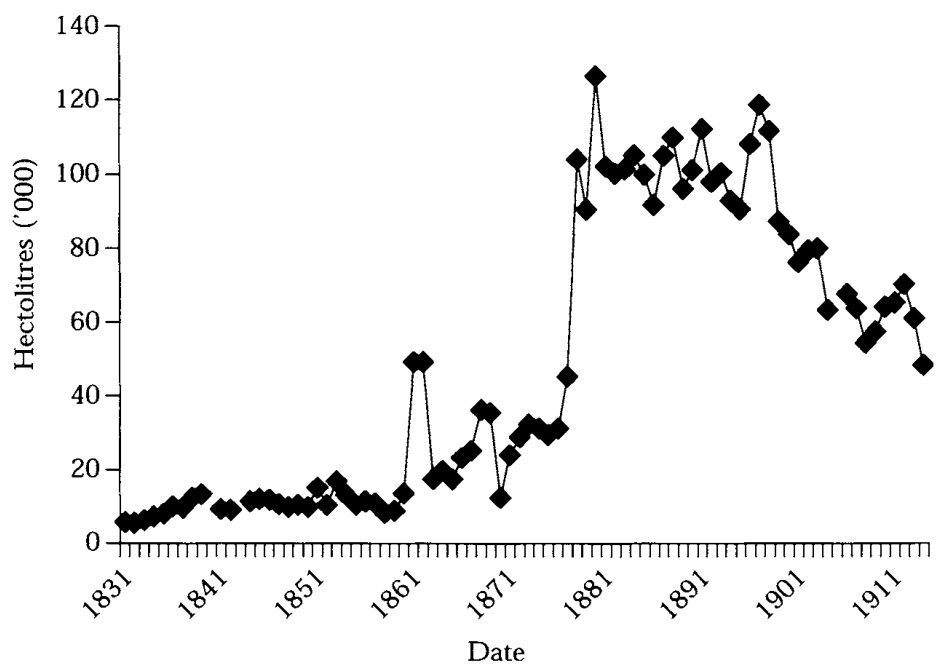

Figure 4. Exports of champagne to Britain, 1831-1911

Source: Tableau Général du Commerce 


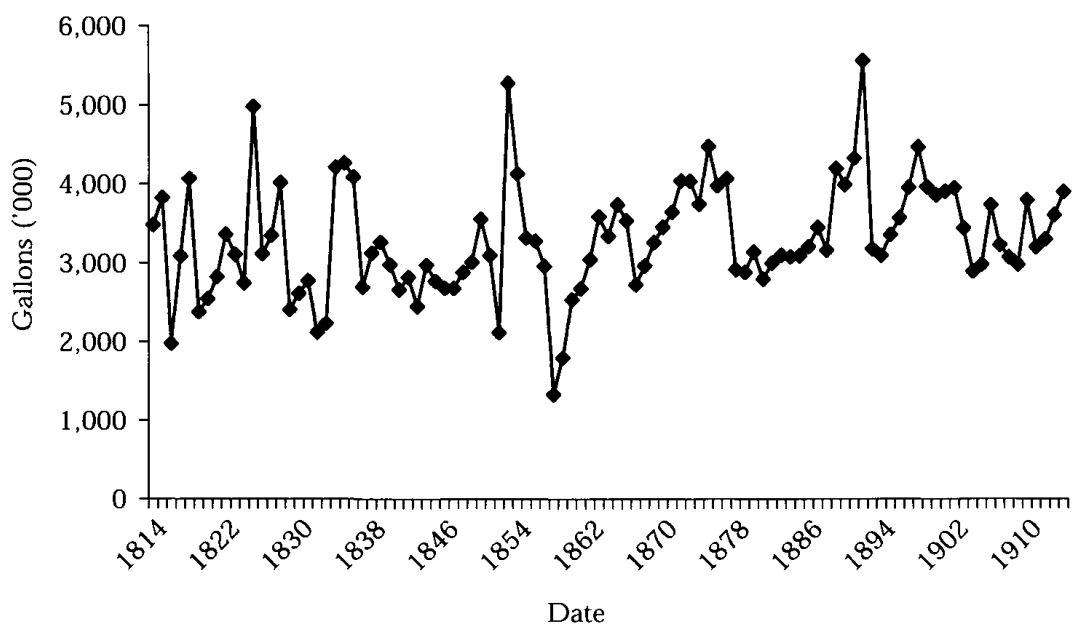

Figure 5. Port wine imports to the United Kingdom, 1814-1910

Source: Wilson, Alcohol and the nation, pp. 362-3

II

Wine was, and remains, a difficult product to sell. Most wines were made from a variety of grapes, and blending of wines from different regions was common. ${ }^{13}$ As noted above, some wines also required spirits to be added before shipping. Further mixing and strengthening in England was considered by many to be both a legitimate and a necessary part of the trade. ${ }^{14}$ However, the problems of marketing in the nineteenth century were caused not just by the heterogeneous nature of wine, but also by supply volatility. Casson has suggested three types of volatility, which organizational structures have to overcome. ${ }^{15}$ In the first instance, important structural changes in the market could create new opportunities to trade. Gladstone's fiscal and legal innovations of 1860-2 created conditions which significantly increased the size of the potential market for wine both by reducing duties and by creating new marketing channels for its sale. These changes, together with improvements in transport, also reduced entry costs for new regions to trade with the United Kingdom. A second type of volatility concerns the fluctuations in supply and demand within established markets caused, for example, by a harvest failure in Bordeaux, or a business

\footnotetext{
${ }^{13}$ Even quality clarets for the English market in the early nineteenth century were blended with wines from Hermitage or Benicarlo (Spain).

${ }_{14}$ The Safe Food and Drugs Act of 1875 required clear labelling of contents, but permitted the mixing of wines, although not with ingredients 'injurious' to the health. The major problem appears to have been the addition of potato spirit, which contained fusel oil: S. C. on Adulteration of Food Act (P.P. 1874, VI), p. 207. For the 1875 act, see especially French and Phillips, Cheated not poisoned?.

15 Casson, Information and organization, pp. 10-11.
} 


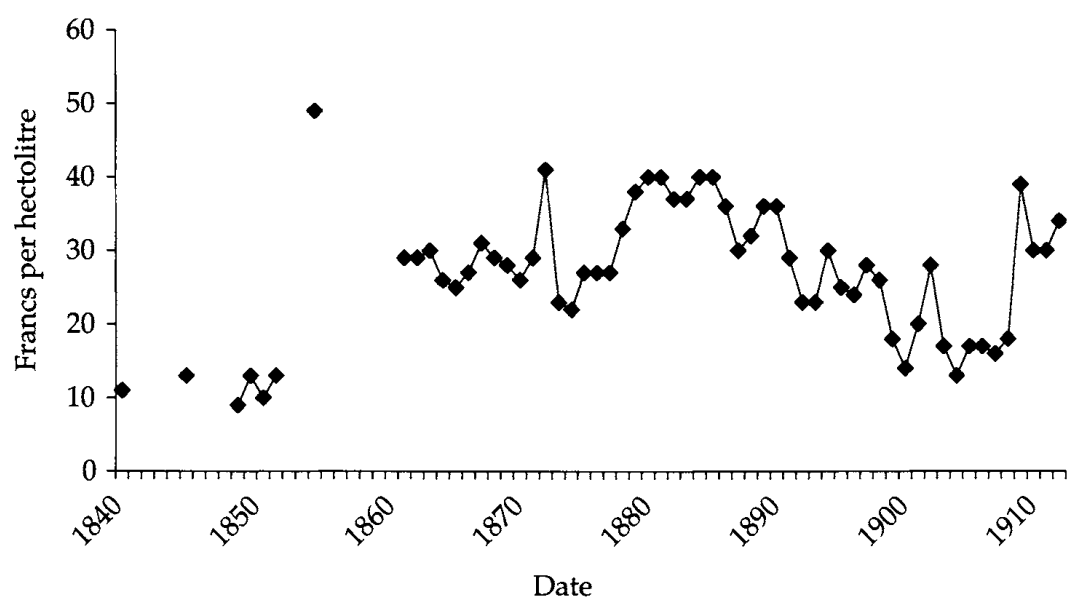

Figure 6. French wine prices, 1840-1913

Sources: Pech, Entreprise viticole, pp. 511-12; Annuaire Statistique, 1934, pp. 62-3

depression in the manufacturing districts of northern England. Although the timing of these events cannot be predicted accurately, they are not entirely unexpected and short-term movements in prices are usually sufficient to balance supply with demand again. However, an additional problem with wine is that quality also changes with each vintage, increasing the problem of classification along the commodity chain.

Finally, Casson suggests a third type of volatility, which is associated with 'breakdowns and interruption of supply that disrupt the equilibrium flow'. ${ }^{16}$ In the nineteenth century there were a number of important breakdowns in the supply of wine, which lasted several years. These were caused by new diseases brought from North America, a negative consequence of the faster voyage times in the Atlantic economy. The first was oidium or powdery mildew, which both reduced harvests and wine quality, especially between 1853 and 1856 , and caused prices to soar briefly. ${ }^{17}$ Phylloxera, a disease that in time required the replanting of virtually all of Europe's vineyards, followed. ${ }^{18}$ Especially relevant here is what happened in France, where production slumped from an average of 58 million hectolitres a year in 1871/5 to 26 million in $1886 / 90$, and average prices rose by one-third between the early 1870 s and the early $1880 \mathrm{~s}$, before declining once more in the face of massive imports and a recovery in domestic production (figure 6). ${ }^{19} \mathrm{Per}$

\footnotetext{
${ }^{16}$ Ibid., p. 11.

17 The solution to oidium was to dust the vines with sulphur.

${ }_{18}$ Although the disease was identified in France in the 1860 s, many of Europe's vineyards were not infected until the twentieth century. See especially Ordish, Wine blight and Pouget, Histoire de la lutte.

${ }_{19}$ Direction Générale, Annuaire statistique, p. 63.
} 
caput consumption in Britain therefore started to decline at the same time as domestic supplies were falling fast in France. Although there were various ways of treating phylloxera, such as the frequent flooding of vineyards or injecting the soil with sulphocarbonates or carbon disulphide, these were too expensive for most producers. The only effective long-term cure was to plant phylloxera-immune American vines, which were then grafted with European scions. The third disease was downy mildew whose appearance in the 1880 s not only reduced the size of harvests, but more importantly ruined the quality. Once a solution was found to downy mildew (treatment with 'Bordeaux mixture'), the attacks from this disease and from oidium became limited to those years when growers were unable to take preventive measures.

The wine trade in producer countries responded to these supply disruptions in two different ways: by allowing the shortage of good-quality wine to increase prices, or by reducing quality with the use of cheaper, inferior wines from other regions to compensate for the smaller local harvests. For example, oidium caused the price of high-quality mature sherries to triple in Britain between $1850 / 3$ and $1860 / 3$, but lower import duties and the ability of shippers to export wines from other regions as 'sherry' actually led to a fall in prices for the cheapest wines. ${ }^{20}$ In fact, London prices for a wide range of ordinary wines from Iberia stagnated over several decades, despite significant fluctuations in both the size and quality of the vintages, and the tendency for wine prices in producer countries to increase from the late 1870 s (figure 7). The same was true of cheap claret. Ridley $\mathcal{G}$ Co.'s Wine and Spirit Trade Circular, a leading trade journal for the British market, noted that in Bordeaux a consequence of the significant decrease in harvest size caused by phylloxera was that:

no pure Claret can now be put on board under $£ 8$, and then of less satisfactory quality than was a few years since easily obtainable at $£, 5$; whilst blends with Spanish Red, South of France, and other Wines are sold, occasionally under their true designation, but generally under the usurped title of 'Claret', at from $£ 5$ to $£ 7$ per hhd. ${ }^{21}$

Therefore although shippers supplied cheap wines at stable prices, the quality often varied considerably, making the need for consumer information crucial, not just for the expensive 'fine' wines, but also for cheap wines. There are two major factors to consider when determining a wine's quality, namely its 'growth' and the 'vintage'. Growth can be defined as the natural environment of a vineyard (the terroir) and the technology and skills used in the production of the wine. This information could then be shown by using the name (brand) of the grower and/or the shipper. Adding the year of production (vintage) provided information on the annual changes in quality. Price differences for wines from vineyards found in a relatively

\footnotetext{
${ }^{20}$ Shaw, Wine, p. 235; Simpson, Too little regulation?

${ }^{21}$ Nov. 1891 , p. 627 . Published under a number of slightly different titles from 1848 , Ridley's was often critical of the manipulation of wine by foreign producers, but more tolerant of the same practice when undertaken by British merchants: Ridley's, Jan. 1881, p. 5 . A hogshead (hhd.) was equivalent to between 220 and 225 litres.
} 


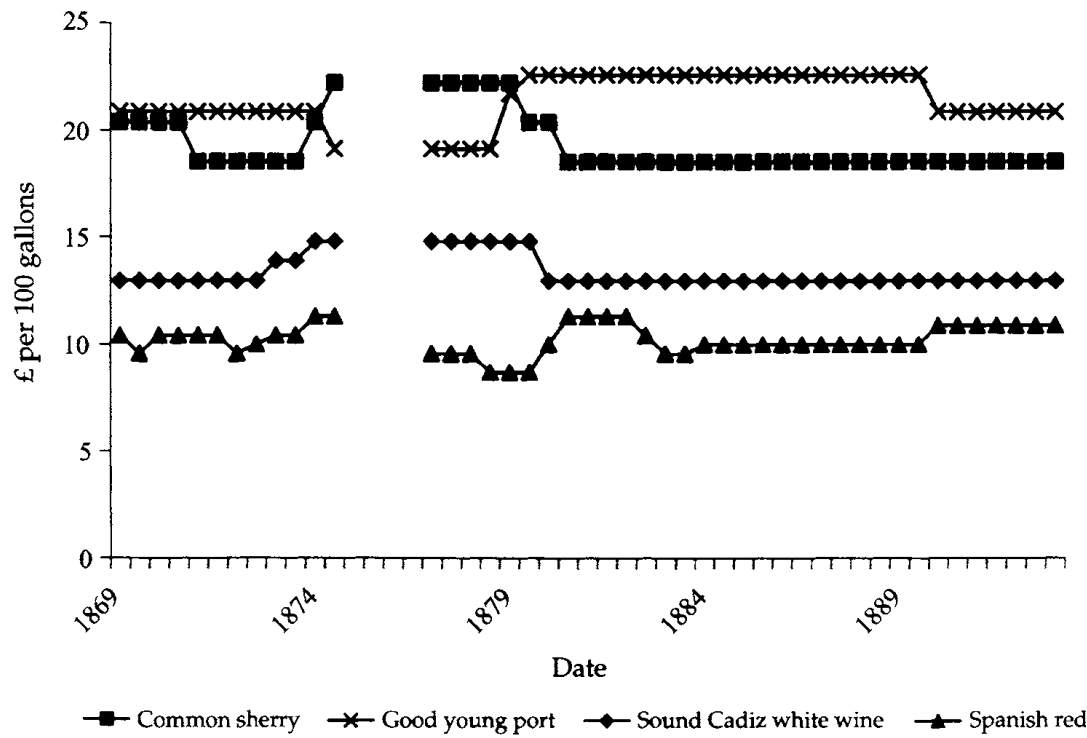

Figure 7. Prices of cheap Iberian wines, 1869-1894

Source: Ridley's, various years

small geographical area could be significant. Thus in Bordeaux's Haut Médoc, red wine in a particular year could range from 300 francs per tun (900 litres) for a paysan growth, to 5,000 francs for the first-class growths. ${ }^{22}$ Of perhaps even greater importance for the wine market was the fact that after a good vintage, the wine of a less well-known grower might sell for more than the price of a top château after a poor one. ${ }^{23}$

Price differences of these magnitudes created strong incentives for individuals along the commodity chain to benefit from the problems of incomplete information. The situation was further complicated in the 1870 s and 1880 s by the general shortage of wines and by high prices. There was also the potential risk that a serious decline in a wine's quality, or consumers' concern about the widespread sale of adulterated imitations, might threaten the reputation not just of the cheaper wines, but also of the quality ones. As Akerlof has argued, asymmetries of information where the buyer has insufficient knowledge of the quality of a product prior to purchase can lead to a situation whereby bad goods drive out the good. ${ }^{24}$ The next two sections consider how producers in some

\footnotetext{
${ }^{22}$ Cocks and Feret, Bordeaux et ses vins, 8th edn., p. 89. Likewise González Byass sold sherry at prices ranging between $£ 18$ and $£ 150$ per butt (500 litres) in 1878: Montañés, González Byass, p. 264.

${ }^{23}$ For example wines from the leading growers (premier crus) in 1853 sold for less than some of the crus paysans of 1854: Markham, 1855, p. 369.

24 Akerlof, 'Market for "lemons"'.
} 
regions were more successful than others in avoiding these problems. Given the difficulties in achieving voluntary agreements among economic agents to control wine quality at the source of production, a number of private strategies, such as the development of brand names or the production of 'vintage' wines were devised to provide information to consumers, with varying degrees of success.

\section{III}

The fact that sherry and port accounted for approximately three-quarters of all British imports of wine before 1860 implied that the potential new wine-drinking public were already aware of these names, although the commercial structure for their sale was that of quality wines. As fortified wines, they also had the advantage over unfortified wines in that they kept longer once the bottle was open. Total sherry exports rose from about 15 million litres a year in the 1850 s to almost 40 million in the early $1870 \mathrm{~s} .{ }^{25}$ However, by the early $1890 \mathrm{~s}$ the figure had fallen to less than 20 million litres, and imports to the United Kingdom were less than a quarter of what they had been at their peak (figure 2). Contemporaries argued that this fall was caused by a decline in the drink's 'reputation', the result of the sale as 'sherry' of large quantities of poor-quality wines, some of which were prejudicial to the drinker's health. ${ }^{26}$ However, a similar combination of high prices and widespread adulteration had led to a decline in the imports of port from the mid-1830s to the early $1850 \mathrm{~s}$, but these then recovered (figure 5), in sharp contrast to sherry. The next point to consider is the attempts by producers to classify their wine for consumers, and then the question of the supply of cheap wines and adulteration.

Both in Jerez and in Porto, trade was dominated by a small number of shippers who sold wine under their own 'brand', thereby assuming responsibility for its quality. One major difference between the two drinks was that by the 1860 s the leading merchants had perfected the production of vintage port, which was made only after a good harvest. This did not imply that high-income consumers could dispense with their local wine merchant, who often matured and bottled the wine, but it did provide information, which was relevant for establishing a national market. Because the decision to classify a harvest as vintage rested with the port shipper alone, the selling of poor-quality wine as 'vintage' would damage his reputation. As this reputation had often been built up over many decades, shortterm opportunistic behaviour was usually discouraged. ${ }^{27}$ By contrast, sherry was a blended wine made from many different harvests, and created

\footnotetext{
${ }^{25}$ Sherry was produced in Jerez de la Frontera, Sanlucar, and Puerto de Santa Maria in the Cadiz Bay region.

${ }^{26}$ Shaw, Wine, p. 217. This section is based on Simpson, Too little regulation?

27 Sellers, Oporto, gives a history of the major port houses.
} 
using the solera. ${ }^{28}$ A few vintage wines were produced, but it was generally believed that sherry remained fresher in casks than in bottles, and the solera system had the advantage of reducing considerably the time it took to mature the wine. The solera therefore made it easier for exporters to produce a standardized product and dispose of wines from the poor vintages, but it provided less information for consumers. Sherry was frequently sold using the brand name of the shipper, and quality identified by numbers or marks rather than by the year. The system was often confusing, as Ridley's noted in 1892:

The public knows so much of vintages and growths of Champagnes, Ports, Clarets, and to a lesser extent of Burgundies and Hocks... . With Sherry the case is very different. And the consumer knows nothing but vague names as Vino de Pasto, Amontillado, Oloroso, etc; the result is that he has less means of judging what price he ought to pay. ${ }^{29}$

As a result, as Duguid has argued, it was often the local wine merchants who established their own brand. ${ }^{30}$ Of these, the most famous was perhaps Harvey's Bristol Cream, which dates from the early 1860s, although the shipper González Byass also started selling Tio Pepe in the 1870 s. $^{31}$ Both of these were expensive wines, and unsuitable for the development of a mass market. However, if the poor classification of sherries provided customers, especially new ones, with limited information on quality, the major factor behind the decline in sales was the concern of consumers regarding the potential health risks associated with the drink.

Sherry was an expensive drink on account of the high cost of land and labour and the low yields, so to meet the demand for cheap white wines after 1860, Jerez's shippers turned to other regions in central and southern Spain. To reduce costs, these wines were often exported shortly after the harvest, and were heavily fortified to stop them turning sour. The success of sherry encouraged producers in other countries to sell their own 'sherry'. Of particular concern to the health authorities in Britain were the 'manufactured' wines, the most notorious perhaps being 'Hamburg sherry', which was made by adding spirits, saccharine, and other substances to 'a light German wine of poor quality'. ${ }^{32}$ When the lower level of duty was extended from $26^{\circ}$ to $30^{\circ}$ proof after 1886 , it was widely reported that chemicals were being added to stabilize cheap Spanish white

\footnotetext{
${ }^{28}$ The solera consists of a series of barrels of similar types of sherry, at different levels of development. When wine is withdrawn for sale from the oldest, it is refilled by wine from the next, and so on along the solera. If only small quantities are removed, then the new wines that have been introduced quickly assume the quality of the old ones.

${ }^{29}$ Ridley's, March 1892, p. 165.

${ }^{30}$ Duguid, 'Developing the brand', p. 26.

${ }^{31}$ For this early date of Harvey's Bristol Cream, see Simpson, Too little regulation? and for Tio Pepe, Montañés, González Byass.

${ }^{32}$ Medical Times and Gazette, quoted in Tovey, Wine revelations.
} 
wines so that they could be imported at the lower duty. ${ }^{33}$ Although this continual and widespread bad publicity made many in Britain believe that 'lemons' had ruined the market for the good wines, it cannot be the only explanation. In particular, the claim made by Dr Thudichum in 1873 regarding the supposed health risks associated with the use of gypsum when crushing the grapes, and sulphur in the fumigation of the casks, applied to all sherries, not just the cheap ones. It was widely debated in both the national and local press, and it was not until some 20 years later that the Lancet published a report showing that these practices were perfectly safe. ${ }^{34}$

The export of adulterated cheap wines from Portugal appears to have been less expensive. ${ }^{35}$ Yet the demand from Britain for cheap port was just as great as that for cheap sherry, although 'good young port' sold for more than either 'common sherry' or 'sound Cadiz white wine' (figure 7). In the late nineteenth century, the price of port was often made more competitive, especially in public houses, by mixing it with cheap Spanish red wines from Tarragona. ${ }^{36}$ Tarragona red sold at half the price of the cheapest port, and the mixing was done by retail wine merchants or publicans, most of whom had personal contact with consumers. Therefore the problem that those involved in the sherry trade failed to solve was not so much that different wines were being mixed and sold as sherry, but rather that their classification was poor, and there were rumours concerning the supposed health risks. Although the quantities of adulterated sherries may have been relatively small, and the quality of 'good' sherry by the 1880 s had perhaps improved significantly from the levels of the $1860 \mathrm{~s}$, demand failed to recover. The situation may suggest that the control of product quality for cheaper wines was best left in the hands of retailers in the United Kingdom, rather than producers in Jerez or Porto. However, before considering this possibility, it is necessary to look first at the experience of two unfortified wines, namely claret and champagne.

\section{IV}

In theory at least, the Bordeaux wine trade appears to have been in a strong position to avoid the problems encountered by the sherry trade in establishing and maintaining product reputation. For quality claret, the

\footnotetext{
${ }^{33}$ Simpson, Too little regulation?. By $1900,81 \%$ of Spanish imports paid 1s. a gallon (compared with just $8 \%$ of Portugal's), but by this date only $37 \%$ of imports of Spanish wines were white.

${ }^{34}$ See Jeffs, Sherry, pp. 95-8.

35 'The one saving feature, as compared with the trade in cheap so-called Sherry, is that shippers of respectable standing at Oporto have not yet condescended, like the leading Xerez and Port St. Mary houses, to traffic in such dangerous commodities, and as the bulk of the trade must always remain in their hands, the evil will not, we hope, be extended beyond its present limit'. Ridley's, Jan. 1887, p. 2.

${ }^{36}$ S.C. on Wine Duties (P.P. 1878-9, XIV), p. 103. By 1896 the United Kingdom was importing more Spanish red than white. When imports from Spain started to decline after 1900 because of problems of quality, Australian wines were used.
} 
classification of the leading growers in 1855 provided a sufficiently accurate guide that has allowed it to remain virtually unchanged to this day. ${ }^{37}$ For the cheaper wines, well-established export houses were able to draw on the produce of a much larger and highly diverse wine district covering almost 200,000 hectares in $1873 .{ }^{38}$ Yet exports from Bordeaux to the United Kingdom, both of quality bottled claret and of ordinary table wines, followed a similar trend, rising rapidly from the 1860 s and then declining equally quickly from the 1880 s (figure 3 ). On the eve of the First World War the United Kingdom imported little more wine from Bordeaux than it had done prior to the early $1860 \mathrm{~s}$.

In 1816 André Jullien published the first classification of Bordeaux's leading vineyards in his Topographie de tous les vignobles connus, which listed five distinctive classes, although specific properties were found in only the first two. ${ }^{39}$ Other lists soon followed, published both in French and in English. ${ }^{40}$ However, it was the Bordeaux Classification of 1855 , compiled by the brokers (courtiers) for the Universal Exhibition of that year, that became the reference for the wine trade and consumers alike. This listed 61 of the Médoc's vineyards and one from the Graves region (Château Haut-Brion) in a five-class classification of red wines. Its success stemmed from three factors. First, rather than being a subjective study based on taste, it used prices that had been paid for different wines over many years. Second, it was the relatively impartial brokers, and not the growers, who compiled it. Finally, wine merchants considered it as only a rough guide, and were quite willing to pay higher or lower prices when they thought a wine warranted it. This was important, because the quality of a château's wine varied not only according to the vintage, but also over time on account of changes in the level of investment and the quality of management skills. ${ }^{41}$

However, the 1855 classification ignored the great majority of vineyards in the region. As these produced many good wines, the increasing popularity of claret encouraged growers to establish their own brand names by adopting an impressive name for their vineyard. The leading wine guide to the region, Cocks and Feret's Bordeaux et ses vins, listed only 318 châteaux in its 1868 edition, but the number increased to 800 in 1881 , and to 1,600 in $1900 .^{42}$ Previously obscure vineyards, which perhaps had

\footnotetext{
${ }^{37}$ Château Mouton-Rothschild was promoted to a First Growth in 1973. The 1855 classification also included a two-class classification of white wines.

${ }^{38}$ This was significantly more than it had been earlier in the century. Franck in 1824, for example, gives only 130,000 hectares: Traité sur les vins, cited in Roudié, Vignobles et vignerons, p. 31.

${ }^{39}$ Jullien, Topographie. Some of the brokers (courtiers) had their own private lists in the eighteenth century. For a history of the classification of Bordeaux wines, see Markham, 1855.

40 For example, in French, Franck, Traité sur les vins (1824), Le guide (1825), Paguierre, Classification (1829) and Cocks, Bordeaux (1850); and in English, Jullien, Topography (1824), Henderson, History (1824), Paguierre, Classification (1828), Redding, Modern wine (1833), and Cocks, Bordeaux (1846).

${ }^{41}$ Only Château Mouton-Rothschild and Château Léoville-Barton have remained with the same family since 1855: Robinson, ed., Oxford companion, p. 245.

${ }^{42}$ See Roudié, Vignobles et vignerons, p. 142.
} 
produced excellent wine to sell under a shipper's name, now gained an identity for themselves.

Having established a recognizable brand name, growers had to protect it. To prevent merchants from mixing their wines with others, estate bottling was introduced by some producers, and with it the use of distinctive labels and branded corks. British wholesale merchants criticized the trend towards château bottling, claiming that it was 'a guarantee of origin, not of quality', ${ }^{43}$ but also realized that, as happened with champagne, its widespread use would give the producers a greater control of the market and a greater share of the profits at the expense of the merchants.

The experiment in château bottling was only temporary, however, not because the concept was flawed, but as a result of the breakdown in the supply of quality wines. The appearance of downy mildew significantly reduced harvests in the Bordeaux region between 1882 and 1886 , but-more importantly-ruined their quality. After the harvest of 1884, Château Lafite sold its wine for $£ 14$ per hogshead, with 'the right to bottle at the Château with the brand and label'. ${ }^{44}$ Unfortunately, only after part of the consignment had been sold by the shipper several years later was it discovered that the wine had turned bad. Following the legal dispute over who was responsible, together with the bad publicity generated, château bottling lost its popularity until the 1920s.

The potential threat caused to growers by phylloxera was even greater. Not only would they have to replant the dead vines, but there was a fear that the immune American root-stock used as a replacement would reduce the quality of the leading wines. Producers of quality wines therefore resorted to the heavy use of chemicals and fertilizers and the flooding of vineyards in a successful, but expensive, attempt to delay the spread of the disease. Therefore, while the smaller vineyards of the Gironde, whose owners could not afford such measures, were being devastated by phylloxera, the leading producers of red wine in the Médoc actually increased output. ${ }^{45}$ Ironically, these successful attempts to delay phylloxera resulted in a decline in quality-precisely what the producers had been attempting to avoid. Château Margaux's output, for example, reportedly increased from 450 hogsheads of 'premier wine' in the early 1880 s to between 1,200 and 1,400 hogsheads of 'indifferent' or 'bad'-quality wine in $1903 .{ }^{46}$

\footnotetext{
43 Army \& Navy Co-operative Society, cited in Ridley's, 12 June 1889, p. 298.

44 Ridley's, Jan. 1887 , p. 35.

45 Taking $1864 / 78$ as 100 , the output for the whole of the Gironde fell to 78 in $1888 / 97$, but that of the Grand crus of the Médoc increased to 121: Lafforgue, 'Cent cinquante ans', p. 301; Pijassou, Le Médoc, pp. 776-7. Château Latour, for example, increased output by $252 \%$ between $1879 / 87$ and 1898/1907: Higounet, ed., Chateau Latour, p. 297.

${ }^{46}$ Ridley's, April 1903, p. 675.
} 
The abundant supplies of not very good wine from the top growers encouraged retail merchants to exploit the brand names that had been created by the 1855 Classification. Thus it was argued that:

The Public, who unfortunately know more about Growths, than Vintages, receive Circulars offering Château this or Château that at apparently extremely low rates, and on the strength of the name, purchase Wines, which can but prove intensely disappointing. They then are apt to argue that, if wines bearing the names of the best estates of the Médoc be so inferior, those of lower grade must be bad indeed. Thus their faith in Claret, instead of in the merchant, who has sold it them, is shaken, and an inducement is at hand to try Wine from some other districts. ${ }^{47}$

Demand in Britain for quality claret fell significantly and if this was sometimes explained by the growing popularity of smoking and drinking coffee instead of drinking fine claret after dinner, the absence of good vintages from the early 1880 s and the decline in the reputation of the leading brands were contributing factors. ${ }^{48}$ The apparent shift in market control backwards along the supply chain from the Bordeaux merchants (négociants) to the producers in the three decades following the 1855 Classification and the introduction of château bottling, was perhaps more illusionary than real. Virtually all wines, even those of the leading châteaux, were purchased by the négociants shortly after the harvest, and matured in their Bordeaux cellars before being shipped. However, the difficulties of the major Médoc growers following the mildew years of $1882 / 6$ saw the négociants strengthen their position significantly. In particular, the continual financial difficulties of the leading growers led many of them in 1907 and 1908 to enter into price agreements (abonnements) for five or more harvests with individual shippers, selling their wine at a low, but guaranteed, price. ${ }^{49}$ Backward integration through the purchase of a château by the négociants (or their families) also increased in these years.

The measurement of trade by volume disguises the real significance of market change, as it was the British demand for small quantities of very fine wines that had produced the prosperity from the 1860 s to the early 1880 s. Another problem is that although French trade statistics show wine exported in bottles from the Gironde, unknown quantities of high-quality, young wines were also exported in barrels to be bottled at their destination. As red wine production from the leading growers almost doubled in the five-year period immediately before the outbreak

\footnotetext{
${ }^{47}$ Ibid., 11 Sept. 1897.

48 'English habits. . have undergone a considerable change during the past 30 years, and the afterdinner half-hour is now monopolized by coffee and tobacco, while Britons have not yet accustomed themselves to serve fine claret or burgundy with roast meat or game': Letter from Gilbey to The Times, 29 Sept. 1896.

${ }^{49}$ Most of the leading growers (Ch. Lafite, Latour, Margaux, Haut-Brion, Mouton-Rothschild, and others) were involved: Cocks and Feret, Bordeaux et ses vins, 8th edn., pp. xviii-xxii.
} 
Table 2. Indicators of Bordeaux's quality wine production and exports

\begin{tabular}{lccc}
\hline & $1877 / 1881$ & $1900 / 1904$ & $\%$ change \\
$\begin{array}{l}\text { Production } \\
\text { Exports }\end{array}$ & 39,375 & 76,932 & +95 \\
Total exports & 100,861 & 44,606 & -56 \\
Of which & & & \\
$\quad$ Britain & 47,210 & 17,724 & -62 \\
$\quad$ All other markets & 53,651 & 26,882 & -50 \\
Other European markets & 13,486 & 1,230 & -24 \\
Non-European markets & 40,165 & 16,652 & -59 \\
Of which & 21,478 & 2,695 & -87 \\
Latin America & 6,254 & 4,528 & -28 \\
North America & - & 6,229 & \\
French colonies & 4,551 & - & \\
Dutch Indies & 1,630 & 3,200 & \\
British India & 6,252 & & \\
Other countries & & & \\
\hline
\end{tabular}

Notes: Quantities in hectolitres. Production is red wine from the leading growers (grands crus) of the Médoc (Château Haut-Brion is excluded owing to the absence of output figures for 1877/81). Exports include all wine in bottles. Sources: Cocks and Feret, Bordeaux et ses vins, 7th edn., pp. 104-5 and 8th edn., pp. 90-1; Direction Générale des Douanes, Tableau Général du commerce, various years.

of mildew and the turn of the twentieth century, exports of all bottled wines from Bordeaux fell by more than 50 per cent (table 2). Elsewhere the problems regarding reputation, together with rising tariffs, were also responsible for weakening demand, so that the British market in 1900/4 remained larger than that of the rest of Europe and North America combined. Sales of bottled claret to Sweden fell by 86 per cent, to Germany by 43 per cent, to the Netherlands by 42 per cent, to North America by 26 per cent, and only Belgium saw an increase, by 38 per cent. ${ }^{50}$ However the weakness of this source is apparent from the inclusion of both Latin American and French colonial markets, which in general imported cheaper wines than those sold in Europe. Instead of being caused by difficulties with reputation, the decline in sales to Latin America can be attributed to a combination of growing national production and rising tariffs. ${ }^{51}$ Tariffs were obviously not a factor in France's colonial markets, and by 1900/4 Senegal had established itself as the third largest market for bottled claret, after Britain and the United States. ${ }^{52}$

\footnotetext{
${ }^{50} 1$ include those years when no figures are given (Germany 1881, Canada 1880, 1901, and 1902, and Sweden, 1904), even though some exports are probably included in 'all other countries' for these years. By excluding these years, the decline in imports is in Germany, $-55 \%$, in North America, $-23 \%$, and in Sweden, $-82 \%$.

${ }^{51}$ Salavert, Le commerce des vins, pp. 187-8. For tariffs, Cocks and Feret, Bordeaux et ses vins, 8th edn., pp. 1051-64.

${ }_{52}$ Export to Senegal averaged 3.7 million hectolitres in $1900 / 4$, against 17.7 million to Britain, and 4.1 million to the United States.
} 
The cause of the market loss for the cheaper Bordeaux wines was slightly different. Domestic wine shortages led to prices increasing in France by one-third from the early 1870 s to the early 1880 s, and the rise would have been even greater if it had not been for the high level of imports, and the 'manufacture' of wines. ${ }^{53}$ In response to the smaller harvests, Bordeaux merchants tried to keep prices low by mixing with inferior, imported wines. By the mid-1880s Bordeaux was itself importing more wine than it was exporting, leading the British consul to note that 'it is probable that about 50 per cent of all wines shipped from here last year to British ports in wood were "vins de cargaison", 54 The British press went a step further. According to The Telegraph,

An immense proportion of the Wine sold in England as Claret has nothing to do with the banks of the Garonne, save that harsh heavy vintages have been brought from Spain and Italy, and dried currants from Greece, there to be manipulated and re-shipped to England and the rest of the World as Lafite, Larose, St. Julien, and St. Estephe. ${ }^{55}$

Although it seems unlikely that wines of the 1855 Classification actually suffered this fate, the frequent newspaper references to the supposed mixing with foreign wines or-even worse-adulteration, undermined claret's reputation, just as had happened earlier for sherry. Despite the fact that the French wine market switched from shortage to over-production in the early twentieth century, imports to Britain continued to fall. Once more this can be explained by adulteration, but this time by 'basis wines', which were manufactured in Britain from imported grape must and other substances, and then mixed with imported French wines. According to Ridley's, 'people drink so called "Claret", composed of one-third of the genuine article and two-thirds of the British imposition, and condemn, not the latter, but Claret'.56

It could be argued that Bordeaux's merchants were making a necessary business decision when they looked elsewhere for wines because of the high prices and poor quality of local wine. Nevertheless, this was not how local growers viewed the problem, especially as many were suffering in the $1880 \mathrm{~s}$ and 1890 s from the heavy costs associated not only with downy mildew, but also with replanting their vines after phylloxera. They lobbied the government, and in 1899 the free ports were closed, making it prohibitively expensive to import foreign wines for blending purposes. ${ }^{57}$ In France, the

\footnotetext{
${ }^{53}$ Imports increased from the equivalent of less than $1 \%$ of production in the early $1870 \mathrm{~s}$, to onethird in the 1880 s. In 1891 , domestic production was 30 million hectolitres, imports came to 12 million and exports to just 2 million: Direction Générale, Annuaire statistique, pp. 63, 179-80.

54 P.P., Consular report, Bordeaux, 1889, no. 501, p. 9. For trade, see Roudié, Vignobles et vignerons, p. 180

${ }^{55}$ Cited in Ridley's, July 1887 , p. 315.

56 Ibid., April 1906, p. 338.

${ }^{57}$ French tariffs on imported wine for domestic consumption were raised significantly in 1892 , but no duty was paid if it was for re-exporting: Gallinato-Contino, 'Les entrepôts spéciaux'; Roudié, Vignobles et vignerons, pp. 211-12.
} 
unprecedented amount of scientific research generated by the attempts to combat vine diseases provided growers with the means to improve grape yields, which rose from 21 hectolitres per hectare in the 1860 s to 33 hectolitres in the $1900 \mathrm{~s}$, although at the cost of poorer quality wines. ${ }^{58}$ As prices continued to fall during the first decade of the twentieth century, growers now lobbied to restrict the use of the name 'Bordeaux' to only those wines produced in the Gironde. The framework for the creation of a regional delimitation was provided by the 1905 law, although it was only in 1911 that boundaries were established, and only after the First World War that the administrative machinery was in place to enforce it. However, even a well-functioning regional appellation was no guarantee of quality. If it successfully raised prices by excluding poor-quality wines produced outside the region, this simply provided an incentive to produce more locally. Only with the introduction from the mid-1930s of the appellation d'origine contrôlée, which controlled the nature of grape and wine production, could consumers be guaranteed at least a minimum quality standard from 'Bordeaux'.

Champagne was already an important drink by the eighteenth century, but the region's proximity to Paris had the consequence that it produced much greater quantities of red wine until the $1850 \mathrm{~s}$, when it began to face fierce competition from the Midi. From the late 1840 s to the 1900 s total champagne sales increased almost five times, from 7 million bottles a year to 32 million. ${ }^{59}$ Grapes which had previously been used for table wines were switched to champagne, but technological change in wine making was also important in increasing output. In 1837 André François discovered how growers could measure the exact amount of sugar that needed to be added each year to obtain a correct fermentation. Until this date large quantities of wine often failed to become effervescent, or alternatively the pressure became so great that 'an enormous proportion of bottles would burst'. ${ }^{60}$ Advances in glass-making techniques allowed stronger bottles to be produced, reducing the loss from bottle breakage from about 25 per cent in the late 1850 s to 10 per cent by the 1870 s. $^{61}$

Most of the vineyards in the Champagne region were small, family concerns, and the growers sold their grapes to firms that possessed the capital and skills to make the wine. As a sparkling wine, champagne could only be sold in bottles, and it was the winemaking firms rather than those involved

\footnotetext{
${ }^{58}$ Calculated from Direction Générale, Annuaire statistique, pp. 62-3. The methods include the use of hybrid vines, the heavy use of artificial fertilizers, and light prunings.

59 The growth in trade was foreseen by Maizière in 1848 , when he noted that 'sparkling wines have made fortunes for twenty merchants, ensure an honest living for a hundred more, and provide a prompt and profitable outlet for the product of every class of grower; yet the present state of the trade, already ten times as lucrative as the old, is only in its infancy and can multiply tenfold within a few generations': cited in Faith, Story of champagne, pp. 55, 209.

${ }^{60}$ Simon, Champagne trade, p. 100 . See also Paul, Science, vine, and wine, ch. 7.

61 Guy, When champagne became French, p. 70.
} 
in retailing that were best placed to establish brand names. ${ }^{62}$ The changes in taste in the British market in the late 1860 s to dry champagne allowed producers to establish 'vintage' wines similar to port, and thereby a system of classification which made it easier for consumers to identify the best wines. ${ }^{63}$ According to one authority, these changes helped to transform wine retailing in Britain from one of 'long credit and bad debts, limited business and high profits' to one of cash payments and higher turnover. ${ }^{64}$ Attempts by some British wine merchants to have their own names placed on the bottles met with only limited success. Gilbey's, for example, which was by far the largest of the retailers, sold only producer branded champagne after 1882, although the Victoria Wine Company's list of 1896 continued to include seven 'house' champagnes, as well as 23 producer branded champagnes. ${ }^{65}$ Despite the opposition from the domestic wine trade, there were merits to the producer brands, which even Ridley's, the mouthpiece of the wholesale trade, recognized: 'the system of brands, whatever its faults may be, is supposed to act as a guarantee to the public, who are content to pay a higher figure for a branded article, rather than incur the risk of not obtaining it genuine if they dispense with the guarantee'. ${ }^{66}$

The champagne producers were therefore the most successful in establishing brand names, so much so that one writer noted in 1890 that 'within ten years we will no longer recognise the name of champagne, but only those of Roederer, Planckaert, Bollinger, without any idea what the wines will be made out of' ${ }^{67}$ If the commercial strength of these brands was so strong, why did exports to Britain start to decline from around 1900? No doubt the decline was partly caused by the combination of higher duties for champagne after 1888, and rising prices because of supply shortages caused by phylloxera. André Simon, writing in 1905, also suggests that the novelty of drinking 'vintage' champagne had declined, as houses were declaring a harvest to be 'vintage' more frequently 'than in the past'. ${ }^{68}$ However it also seems likely that the decline in the sales of the best champagne was in part a result of commercial strategy, as producers recognized that their leading wines could not attract a mass market if they were being branded as a luxury product. Sales strategies were changed so that producers gained a larger share of the profits, and some began to charge hotels and restaurants if they wanted to stock their particular brand. It was a strategy which implied lower volumes, and made producers much more vulnerable to changes in fashion, such as the growth in whisky drinking at the turn of the century.

\footnotetext{
${ }^{62}$ Once it leaves the Maison, champagne does not improve in the bottle.

${ }^{63}$ Simon, Champagne trade, pp. 99, 137. This author notes that the taste for sweet champagne lasted longer outside London. For example, the shipper George Goulet exported sweet champagne with $16 \%$ liquor content to a merchant in Birmingham, but with only $2 \%$ to London.

${ }^{64}$ Simon, Champagne trade, p. 137.

${ }^{65}$ Faith, Story of champagne, p. 73; Briggs, Wine for sale, p. 83.

${ }^{66}$ Ridley's, Jan. 1884, p. 3.

${ }^{67}$ Lamarre, cited in Faith, Story of champagne, p. 78.

${ }^{68}$ Simon, Champagne trade, p. 147.
} 
Yet the leading champagne brands probably accounted for only a relatively small part of the British market in terms of volume. The rapid growth everywhere in the demand for champagne, the limited area of suitable land, and the appearance of phylloxera after 1890, led to an increase in the sales of poor-quality wines. Fraud, which had been 'a peripheral concern in the 1890 s', became 'the central issue for producers of both ordinary and fine wines at the turn of the century'. ${ }^{69}$ Champagne producers had been more successful than other wine producers in defending their wines, and in 1889 they succeeded in getting a judgement that forbade producers from other regions to use the words 'champagne' or 'vins de champagne' in France. Implementation was more difficult, however. Furthermore, the judgement failed to stop Champagne's own producers buying wines from other regions, mixing them with local wines, and then selling them as 'champagne', a practice which was especially widespread after the disastrous harvests between 1908 and $1910{ }^{70}$ Consumers could still find quality champagne, but the demand for the cheaper brands declined rapidly in Britain after 1900. Growers once more looked to create a regulatory authority, establishing a regional appellation in 1911 by restricting the production of champagne to grapes produced in a number of clearly defined areas.

\section{V}

In terms of value, approximately 60 per cent of all food and drink consumed in Britain was imported by $1914 .^{71}$ This dependence on imports, together with the rapid growth in population, especially in urban areas, and the increase in real disposable incomes, encouraged new forms of market organization, sometimes called the 'retailing revolution'. Among these changes were the increasing importance of brand names, advertising, and the appearance of large multiple retail outlets. In particular, the growing dependence of British consumers on world markets helped to change the location of power along the commodity chain. For example, the import of frozen meat reduced the need for skilled butchers but required guaranteed outlets for the "vast quantities of frozen and later chilled meat that were pouring into the United Kingdom' ${ }^{72}$ By 1910 , a total of only 10 UK firms had between them established a total of 3,684 branches, ${ }^{73}$ and it was these

\footnotetext{
${ }^{69}$ Guy, When champagne became French, p. 119. However, Tovey noted in 1870 that 'even at Epernay and other places in Champagne it is well known that there are houses which use but little of the wine of the district in the manufacture of their wines': Tovey, Champagne, p. 19.

${ }^{70}$ Although The Times reminded consumers of the large reserves of quality wines in the region, and also of the good reputation of the leading brands, it also noted that the champagne vintage of 1908 'had been the subject of so many irresponsible statements and misleading comments and conclusions in the press': The Times, 19 Nov. 1908, p. 9. See also Daily Telegraph, 28 Aug. and 3 Sep. 1903, cited in Guy, When champagne became French, p. 124.

71 Turner, 'Agricultural output', pp. 224-5.

72 Jefferys, Retail trading in Britain, p. 190. Imports of meat increased from $10 \%$ of the total in 1870 to $37 \%$ in 1896 : ibid., p. 182.

${ }^{73}$ Ibid., p. 187.
} 
firms that controlled product quality, established brands, and enjoyed scale economies in marketing. Likewise with coffee, the growing economies of scale in roasting and packaging (the latter especially after vacuum sealing was invented in 1900) encouraged a concentration in the number of firms in the consuming countries, where a growing share of the value was added. ${ }^{74}$ Because demand conditions were more volatile than supply, the commodity chain was market- rather than producer-led, and brands were established in the importing rather than the exporting countries. ${ }^{75}$

In the first half of the nineteenth century, like many other traders, the British wine merchant was skilled, ${ }^{76}$ having to be able to select suitable wines, blend them to the tastes of a particular consumer, and stop them from spoiling. Bottling was another skilled task, often undertaken on the client's premises. Retail wine merchants in general responded to the wants and needs of high-income consumers. ${ }^{77}$ Lower duties and the 'Single Bottle Act' of 1861 provided retailers with opportunities to package and market wines in new ways. The Victoria Wine Company, which was established in 1865 in Mark Lane in the City of London, had by 1886 some 98 stores throughout the country. ${ }^{78}$ The company bottled its own wines, and placed the fact that they were 'unadulterated' prominently in its advertisements. ${ }^{79}$ Gilbey's was even more successful, being responsible in 1875 for 5 per cent of all wine sold, six times the share of its nearest rival. ${ }^{80}$ Taking advantage of the lower duties and especially the 'Single Bottle Act', it sold all its wine in sealed and labelled bottles. ${ }^{81}$ The firm's success was achieved by importing wines in bulk directly from the country of origin, and by the use of its 'Castle' brand and of some 2,000 carefully monitored agents throughout the country. These agents were often already well-established grocers, and were stocked with a selection from Gilbey's 200 different varieties of drinks. Sales on this scale allowed the company to spend heavily on advertising.

Yet the impressive results of these two companies were insufficient to halt the decline in wine sales from the mid-1870s. A number of problems can be identified. First, and according to Jefferys, large-scale retailers had few advantages over smaller ones unless they could achieve buying and selling economies, and introduce standardization and stock control. ${ }^{82}$ There were few economies of scale in wine production, and therefore higher sales did

\footnotetext{
${ }^{74}$ Over three-quarters of the retail price of coffee in the grocery trade was added in consuming countries by 1935: Topik, 'Integration', p. 60.

75 See especially Casson, Information and organization, pp. 28-9.

${ }^{76}$ Jefferys, Retail trading in Britain, p. 2.

${ }_{77}$ There was, of course, a market for poorer quality wines and the adulteration of wines prior to 1860 was also important: see especially Redding, Modern wine.

${ }^{78}$ Briggs, Wine for sale, p. 9.

79 Illustrated London Nezws, 13 Dec. 1873, cited in Briggs, Wine for sale, p. 48 . By 1880 the company was listing 16 sherries, together with 14 ports, 8 clarets, and 'sundry wines' including a Hambro sherry (ibid., p. 53).

${ }^{80}$ Faith, Victorian vineyard, p. 12.

81 S.C. on Wine Duties (P.P. 1878-9, XIV), p. 157.

82 Jefferys, Retail trading in Britain.
} 
not lead to lower unit production costs. ${ }^{83}$ The fact that wine quality varied greatly not just from one harvest to the next, but even on an individual vineyard in the same year, led to supply instability and high information costs for importers. Gilbey's, for example, depended on leading shippers in Jerez and Porto to select its wines, although these were sold under Gilbey's own brand. When the firm purchased Château Loudenne in the Médoc in 1875, it was an example of backward integration which appears to have been made as much to reduce information costs in its search to buy suitable wines from local growers, as to cut production costs. ${ }^{84}$ As an investment, the purchase of Château Loudenne occurred at perhaps the worst moment possible and was a drain on company resources, but it did allow Gilbey's to market itself as a wine producer. Another problem was that although the infrastructure provided by the firm's shops reduced the skills that the traditional wine merchant required, in particular the blending of different wine, some specialized knowledge was still needed and a common complaint was that wines were badly stored by grocers.

Although Gladstone had hoped that the legislation of the early $1860 \mathrm{~s}$ would extend wine drinking to other social classes, the evidence suggests that it had only limited success. ${ }^{85}$ In the early 1880 s, a very rough estimate by the British Association claimed that the working class purchased 75 per cent of all beer and spirits, but consumed just 10 per cent of wine. Taking annual per caput consumption at this time as two and a half bottles, this implies that 75 per cent of the population on average drank only one-third of a bottle, and the remainder consumed nine bottles. ${ }^{86}$ For the years 191314 , another survey shows that those with annual incomes of between $£ 150$ and $£ 200$ consumed four times more wine than those with between $£ 50$ and $f 100 .{ }^{87}$ Therefore, given that the middle- and upper-class consumers appear to have continued to account for an important segment of the market, it is possible that demand factors specific to these social groups were at least partly responsible for the fact that per caput consumption of wine declined more than that of either spirits or beer in the late nineteenth century. Traditionally, considerable amounts of port, sherry, and claret had been drunk in rural areas, and contemporaries noted in particular the decline in demand with the onset of the agrarian crisis and the fall in rents after 1873 . However, although sherry imports actually peaked in that year,

\footnotetext{
${ }^{83}$ For potential scale economies in grape and wine production, see Simpson, 'Cooperation and cooperatives'.

${ }^{84}$ Gilbey's first bought wines directly in France in 1863: Maxwell, Half-a-century, p. 18. For Château Loudenne, see especially, Faith, Victorian vineyard.

85 Gladstone's interest in reducing wine duties appears to have derived from the belief that free trade and sobriety went hand in hand: Harrison, Drink and the Victorians, p. 248. Not only did he expect wine consumption and revenue to rise rapidly after the reduction in duties, but he also hoped to change the social habits of drinkers.

86 The 'working class' is taken as $75 \%$. Quoted in Rowntree and Sherwell, Temperance problem, p. 10, my calculation.

${ }^{87}$ Colwyn Report (P.P. 1927, XI), p. 92, cited in Burnett, Liquid pleasure, p. 142.
} 
there were other factors present which help to provide an explanation. ${ }^{88}$ Port imports were also weak during the 1880 s, but then recovered. Declining farm incomes probably reduced demand from this group of consumers, but new potential markets were appearing in the rapidly growing urban centres. For example, rural consumers had traditionally purchased their port and sherry in barrels, and bottled them on their own premises, but urban consumers in general often had limited space for a wine cellar, and preferred to buy their wines already bottled. ${ }^{89}$ Likewise it was argued at the turn of the century that brewers were entering into the wine trade, not just supplying their publicans, but also purchasing wine merchants' businesses. ${ }^{90}$ In other words, changes in real incomes and inequality helped to alter the shape of demand, and this was just as likely to be beneficial for the consumption of some types of wines as prejudicial for others. In particular, it does not explain why urban consumers did not drink more, or why multiple retail outlets were not as successful in marketing wine as they were in marketing other foods and beverages.

\section{VI}

This article has tried to explain why the growth of the British wine market which took place after the changes in duties and retailing laws in the early 1860 s was limited. Imports grew quickly until the mid-1870s, but then fell, and per caput consumption was no greater in 1913 than it had been in 1815 , despite the retail price of the cheapest wines being one-fifth of those in Wellington's time. Why were markets which had been gained after 1860 subsequently lost? This article has argued that producers and shippers had limited success in classifying and guaranteeing the quality of their wines for a changing market. In Jerez the solera system was an admirable method of blending wines and maintaining quality, but provided consumers with too little information about the nature of the wine, especially in a period when widespread adulteration was taking place. By contrast, the 1855 Bordeaux Classification provided good information on the relative merits of the leading claret producers, but the crucial information on the vintage was missing. When vine diseases ruined wine quality in the $1880 \mathrm{~s}$, large quantities of 'villainous trash' were exported, and wines were often marketed by emphasizing their 'growth', rather than the 'vintage'. With both sherry and claret it seems that, as Akerlof predicted, the presence of poor-quality wines had a negative impact on the market for better ones. In the case of sherry and cheap clarets, the drop in quality was caused by poorer wines from other regions or

\footnotetext{
${ }^{88}$ Sherry imports peaked in 1873 , in part because of the rumours that duties were to be raised: PanMontojo, La Bodega del Mundo, p. 106. Thudichum's infamous letter to The Times was published in the same year.

${ }^{89}$ Ridley's, April 1903, p. 241, Sept. 1904, p. 639, and Sept. 1899, p. 621.

${ }^{90}$ See, for example, Ridley's, Sept. 1899 , p. 622 and Jan. 1900, p. 8.
} 
'manufactured wines' being wrongly labelled, but with quality claret it was the consequence of a run of exceptionally poor harvests. In this case, large quantities of poor-quality wines from the leading producers were exported, ruining their reputation, with the result that although they were producing more wine than at any time during the period under discussion, the value of their properties was at its lowest. ${ }^{91}$ By contrast, both champagne and port producers were more successful in protecting their brands than claret producers. Consumers could classify the relative status of a champagne or port by the reputation of the producer/shipper and the quality of the vintage. More important perhaps, there were clearly defined uses for both these wines after the poorer harvests, and these uses did not have a detrimental impact on the quality market. Port shippers were less likely than sherry shippers to ship poor-quality wines, and the leading champagne shippers were the most successful of all, both in creating brands and in protecting their regional identity.

Given the difficulties in establishing objective measures of quality for consumers, the incentive for shippers, especially those who did not have to maintain a reputation for quality wines, was to export large quantities of cheap wines. Ridley's naturally argued that a more efficient guarantee of quality for consumers was provided by the reputation of British wine merchants. As with an increasing number of other foods and beverages by the late nineteenth century, this implies that commodity chains would be 'market'- rather than 'production'-led, and importers would be responsible for classifying and controlling wine quality. They could avoid a poor vintage in a particular region, but make large purchases after good vintages. In other words they could perform, on a larger geographical scale and in the United Kingdom, the sort of operations for which the Bordeaux négociant had traditionally been responsible. This was partly why Gilbey's was initially successful. However, the scale required in co-ordinating purchases from different centres of wine production was considerable, and to develop a brand name as successful as Gilbey's required a considerable capital outlay.

In fact, Gilbey's was probably unique in Europe at this time, and the British wine market differed significantly from that of other countries in many ways. Virtually all quality sherry and port was sold to this market and, despite the problems discussed in this article, the British market remained the largest for bottled claret in the early twentieth century. ${ }^{92}$ Only with champagne did other markets of any size exist. However, although comparisons with other countries regarding quality wine have only limited value, their experience with ordinary wines is relevant. It is difficult to establish long-run price series because of the question of quality, yet the presence of vine diseases, especially from the late 1870 s and 1880 s, drove prices sharply up throughout Europe. The production of artificial wines and the practice of adulteration was at least as widespread in producer countries

${ }^{91}$ For real estate prices, see Pijassou, Le Médoc, and Caziot, Le valeur de la terre.

92 Britain accounted for about one-fifth of Bordeaux's exports in bottles in 1909/11. 
as in Britain..$^{93}$ Per caput wine consumption also declined in France from the $1870 \mathrm{~s}$, from an average of 145 litres per person in 1869-78 to 98 litres in 1883-92. The fact that wine in France and Spain was the alcoholic beverage of first choice implies that the combination of high prices and adulteration caused only a temporary decline in consumption. The recovery in supplies from the 1890s brought about a revival of wine drinking, and by the 1900s annual consumption had reached over 150 litres per person in France. In Britain, by contrast, the market for cheap wines was still very limited when it peaked in the early 1870 s, and in the face of higher prices and falling quality, consumers turned to other alcoholic and non-alcoholic drinks. Therefore although per caput beer consumption also declined slightly in the late nineteenth century, not only was beer cheaper than wine, it was also probably purer. ${ }^{94}$ No doubt many of the claims concerning the adulteration of Spanish 'white' and Bordeaux 'red' were exaggerated, but there was little or no attempt from Jerez or Bordeaux to respond to the charges.

This brings us to a final point, namely the contribution of wine exports to productivity changes in agriculture and, more generally, to economic development. The vine was traditionally grown over large areas of Europe, with the high labour inputs and skills required making it an ideal crop for small family farms. With the coming of the railways and the integration of national commodity markets in the mid-nineteenth century there was an increase in regional specialization even before phylloxera. ${ }^{95}$ New high-yielding hybrids allowed growers to increase output, and by the turn of the century there was over-production in France. The high prices of ordinary wines in the 1870s and 1880s also encouraged an expansion of viticulture, not just in the French colony of Algeria but also in countries such as Argentina or Australia which had previously been dependent on Europe for imports. Unfortunately for European producers, by the first decade of the twentieth century little more than 10 per cent of wine produced was traded internationally and European countries themselves imported approximately 80 per cent of the total. In particular, France was responsible for half the world's imports in 1909/13, and the figure increased over the next couple of decades to reach 80 per cent by $1934 / 8 .{ }^{96}$ There were two reasons why producers found it so difficult to establish new overseas markets. The first

\footnotetext{
${ }^{93}$ In Spain in the late $1880 \mathrm{~s}$ it was estimated that about one-quarter of the wines were manufactured using foreign alcohol as a base: see Simpson, Spanish agriculture, p. 97.

${ }^{94}$ Gourvish and Wilson, British brewing industry, p. 208, suggests that 'dilution and adulteration, the old resort of distressed publicans, seem to have been increasingly stamped out after the mid-1880s, as analysis became common, and brewers fought long and hard to remove the practice of the "long pull". Beer prices remained stable in the second half of the nineteenth century at between $3.5 \mathrm{~d}$. and $6 \mathrm{~d}$. a quart: ibid., p. 207.

${ }^{95}$ For example, France's south west and south east increased their share of the national wine market from $42 \%$ in $1803 / 41$ to $42 \%$ in 1852 , and to $65 \%$ in $1900 / 9$ : Lachiver, Vins, vignes et vignerons, pp. $617-18$.

${ }^{96}$ Calculated from Pinilla and Ayuda, 'Political economy', tab. 2. A large proportion of the wine came from Algeria to be mixed with the wines of the Midi, and then sold in the cities of northern France.
} 
was that imports attracted relatively high levels of duty, with the consequence that the movements of wines between countries were strongly influenced by changes in the prevailing level of duties. ${ }^{97}$ The second factor is the subject of this article, namely the question of quality. In producer countries such as France, the better table wines enjoyed only a modest premium, and the incentives for the vast majority of producers therefore were to maximize output. $^{98}$

In the half century prior to 1914 , the failure of producer-led commodity chains to establish both a reputation for purity and an efficient system for consumers to measure quality, led to the decline in reputation of wines in the British market. The interwar period in general was not a good time for quality wines, and the British market, in particular, was depressed. For table wines, the return to a policy of Imperial Preference for the Dominion wines in 1919, which had been abolished in 1860, helped to reduce imports from France to less than 20 per cent of the total, or just 40 per cent of the figure reached when imports peaked in 1876 . Only from the $1950 \mathrm{~s}$, when the controlled appellations began to guarantee minimum quality, tourists started to visit mainland Europe in significant numbers, and supermarkets stocked wines in large quantities, did the British learn to enjoy Europe's wines once more.

\section{Universidad Pablo de Olivade, Sevilla}

First submitted

Revised version submitted

Accepted
29 October 2002

22 fanuary 2004

25 fanuary 2004

\footnotetext{
${ }^{97}$ For the impact of tariffs on the structure of the international wine market, see especially Simpson, Spanish agriculture, pp. 73-5; Pinilla and Ayuda, 'Political economy', pp. 55-75.

${ }_{98} \mathrm{See}$, for example, the important contribution by Augé-Laribé, Le problème agraire, especially p. 165.
}

\section{Footnote references}

Akerlof, G. A., "The market for "lemons"; quality uncertainty and the market mechanism', $Q u$. F. Econ., 84 (1970), pp. 488-500.

Augé-Laribé, M., Le problème agraire du socialisme. La viticulture industrielle du midi de la France (Paris, 1907).

Briggs, A., Wine for sale: Victoria Wine and the liquor trade, 1860-1984 (1985).

Burnett, J., Liquid pleasure: a social history of drinks in modern Britain (1999).

Casson, M., Information and organization: a new perspective on the theory of the firm (Oxford, 1997).

Caziot, P., Le valeur de la terre (Paris, 1917).

Cocks, C., Bordeaux, its wines and the claret country (1846), translated as Bordeaux, ses environs et ses vins classés par ordre de mérite, guide de l'étranger à Bordeaux et dans la Gironde (Bordeaux, 1850).

Cocks, C. and Feret, É., Bordeaux et ses vins (Bordeaux, 7th edn., 1898; 8th edn., 1908).

Duguid, P., 'Developing the brand: the case of alcohol, 1800-1880', Enterprise $\mathcal{E}$ Soc., 4 (2003), pp. 488-500.

Faith, N., Victorian vineyard: Chateau Loudenne and the Gilbeys (1983).

Faith, N., The story of champagne (Frome, 1988).

Franck, W., Traité sur les vins du Médoc et les autres vins rouges du département de la Gironde (Bordeaux, 1824). 
French, M. and Phillips, J., Cheated not poisoned? Food regulation in the United Kingdom, 1875-1938 (Manchester, 2000).

Gallinato-Contino, B., 'Un débat sur le commerce du vin à la fin du XIXe siècle: le conseil général de la Gironde et les entrepôts spéciaux', in CERHIR, Le vin à travers les âges. Produit de qualité, agent économique (Bordeaux, 2001), pp. 171-82.

Gourvish, T. and Wilson, R., The British brewing industry, 1830-1980 (Cambridge, 1994).

Le guide ou conducteur de l'étranger à Bordeaux (Bordeaux, 1825).

Guy, K. M., When champagne became French: wine and the making of a national identity (Baltimore, 2003).

Harrison, B., Drink and the Victorians (1971).

Henderson, A., The history of ancient and modern wines (1824).

Higounet, C., La Seigneurie et le vignoble de Château Latour: histoire d'un grand cru du Médoc, XIVe-XXe siècle (Bordeaux, 1974).

Jefferys, J. B., Retail trading in Britain, 1850-1950 (Cambridge, 1954).

Jeffs, J., Sherry (1970).

Jullien, A., Topographie de tous les vignobles connus... (1816), translated as The topography of all the known vineyards; containing a description of the kind and quality of their products, and a classification (1824).

Lachiver, M., Vins, vignes et vignerons. Histoire du vignoble français (Lille, 1988).

Lafforgue, G., 'Cent cinquante ans de production viticole en Gironde', Bulletin Technique des Ingénieurs des Services Agricoles, 90 (1954), pp. 293-301.

Maizière, A., Origine et développement du commerce du vin de Champagne (Rheims, 1848).

Markham, D., Jr., 1855: a history of the Bordeaux Classification (New York, 1998).

Maxwell, H., Half-a-century of successful trade (1907).

Montañés, E., La empresa exportadora del ferez. Historia económica de González Byass, 1835-1885 (Cádiz, 2000).

Ordish, G., The great wine blight (1977).

Paguierre, M. Classification and description of the wines of Bordeaux (Edinburgh, 1828), translated as Classification et description des vins de Bordeaux (Paris, 1829).

Pan-Montojo, I. L., La Bodega del Mundo. Historia de la vitivincultura en España, 1800-1936 (Madrid, 1994).

Paul, H. W., Science, vine, and wine in modern France (Cambridge, 1996).

Pech, R., Entreprise viticole et capitalisme en Languedoc-Roussillon (Toulouse, 1975).

Pijassou, R., Le Médoc: un grand vignoble de qualité, 2 vols. (Paris, 1980).

Pinilla, V. and Ayuda, M. I., 'The political economy of the wine trade: Spanish exports and the international market, 1890-1935', Eur. Rev. Econ. Hist., 6 (2002), pp. 51-85.

Pouget, R., Histoire de la lutte contre le phylloxéra de la vigne en France, 1868-1895 (Paris, 1990).

Redding, C., $A$ history and description of modern wine (1833).

Robinson, J., ed., The Oxford companion to wine (Oxford, 1994).

Roudié, P., Vignobles et vignerons du Bordelais, 1850-1980 (Bordeaux, 2nd edn., 1994).

Rowntree, J. and Sherwell, A., The temperance problem and social reform (1899).

Salavert, J., Le commerce des vins de Bordeaux (Bordeaux, 1912).

Sellers, C., Oporto, old and new (1899).

Shaw, T. G., Wine, the vine and the cellar (2nd edn., 1864).

Simon, A. L., The history of the champagne trade in England (1905).

Simpson, J., Spanish agriculture: the long siesta, 1765-1965 (Cambridge, 1995).

Simpson, J., 'Cooperation and cooperatives in southern European wine production', Adv. Agric. Econ. Hist., 1 (2000), pp. 95-126.

Simpson, J., Too little regulation? The British market for sherry, 1840-1890 (in preparation).

Tennent, J. E., Wine, its use and taxation (1855).

Topik, S. C., 'The integration of the world coffee market', in C. L. Núñez, ed., Integration of commodity markets in history, B4 Twelfth International Economic History Congress (Seville, 1998).

Tovey, C., Champagne: its history, manufacture, properties (1870).

Tovey, C., Wine revelations (1880).

Turner, M. E., 'Agricultural output, income and productivity', in E. J. T. Collins, ed., The agrarian history of England and Wales, 7 (Cambridge, 2000), pp. 224-320.

Weir, R. B., 'Obsessed with moderation: the drink trades and the drink question (1870-1930)', Brit. $\mathcal{F}$. Addiction, 79 (1984), pp. 93-107.

Wilson, G. B., Alcohol and the nation (1940).

\section{Official publications}

France, Direction Générale de la France, Annuaire statistique 1933, 50 (Paris, 1934).

France, Direction Générale des Douanes, Tableau générale du commerce de la France (Paris, various years). 
United Kingdom, Report from the Select Committee on Import Duties on Wines (P.P. 1852, XVII).

United Kingdom, Report from the Select Committee on Adulteration of Food Act, 1872 (P.P. 1874, VI).

United Kingdom, Report from the Select Committee on Wine Duties (P.P. 1878-9, XIV).

United Kingdom, Report of the Committee on National Debt and Taxation (Colwyn Report) (P.P. 1927,

$\mathrm{XI}$ ). 